\title{
A BME Idegen Nyelvi Központ Tolmács- és Fordítóképző Központjának őszi konferenciája
}

\author{
(Budapest, BME INYK, 2019. szeptember 27.) \\ Szabó Csilla \\ E-mail:szcsilla@inyk.bme.hu
}

A BME Idegen Nyelvi Központja által szervezett „Öszi Konferencia” minden évben igyekszik valami újdonsággal szolgálni a fordítás és a tolmácsolás iránt érdeklődőknek: oktatóknak, piaci képviselőknek és hallgatóknak egyaránt. A szervezők nem titkolt célja, hogy a Jeromos nap környékén megrendezett konferencia programja hüen tükrözze a képzőintézmény egyik legfőbb törekvését, hogy minél közelebb hozzuk a képzést a nyelvi közvetítői piachoz, és minél inkább csökkentsük a tantermi fordítás/tolmácsolás és a fordító/tolmácspiac között fennálló különbségeket.

Mivel az Idegen Nyelvi Központ tevékenységei között a fordító- és tolmácsképzésen kívül a nyelvoktatás is hangsúlyos szerepet kap, ezért évről évre olyan témákat járunk körül, amelyek szélesebb célközönség számára is érdekesek lehetnek. 2016-es eseményünket a piaci képviselőkkel (Proford, OFFI) közösen rendeztük, a 2017-es őszi konferenciát a mérés-értékelés témájának szenteltük, míg 2018ban a szakfordítás oktatásának modernizációját célul kitüző eTransFair projekt keretében nagyobb szabású nemzetközi konferenciát szerveztünk.

Az interdiszciplináris megközelítés illetve a több, egymást metsző célcsoport érdeklődésének felkeltése motiválta a 2019. szeptember 27-én megrendezett szakmai nap programját is, amelyre két nagy témával készültünk. A délelőtti blokkban a kultúraközi kommunikáció egyes aspektusait vitattuk meg (német nyelvü elöadók segítségével, a német és magyar kultúra közötti hasonlóságokra és különbségekre helyezve a hangsúlyt), délután pedig egy szükebb közönséget vártunk, ahol a tolmácsolás során jelentkező stresszről, illetve a tolmácsoláshoz szükséges puha készségekröl szerveztünk mühelybeszélgetést.

A konferencia első része, amely a DAAD és a Goethe Intézet támogatásával valósult meg, az interkulturális kommunikációra jellemző - elsősorban a fordításhoz, tolmácsoláshoz és nyelvoktatáshoz köthető - jelenségeket mutatta be. A ven-

Hivatkozás: Szabó Cs. 2020. A BME Idegen Nyelvi Központ Tolmács- és Fordítóképző Központjának őszi konferenciája (Budapest, BME INYK, 2019. szeptember 27.) Fordítástudomány 22. évf. 1. szám. 109-112.

DOI: https://doi.org/10.35924/fordtud.22.1.8 
déglátó intézmény képviseletében Fischer Márta igazgatónő köszöntötte a hallgatóságot, majd az Andrássy Egyetem és a DAAD képviseletében Fodor Kinga hangulatos, interaktív elöadása következett Deutsche und Ungarn-Gemeinsamkeiten und interkulturelle Unterschiede címmel. Az elöadó bemutatta a már jól ismert, klasszikus magyar és német sztereotípiákat, valamint felhívta a figyelmet azokra a tulajdonságokra, nemzeti, nyelvhasználati jellemvonásokra, amelyek talán kevésbé szembetünők.

A délelötti szekció második előadását Korencsy Ottó tartotta, aki nemcsak az ELTE Germanisztikai Intézetének képviseletében érkezett, hanem mint akkreditált európai uniós tolmács, s aki főként ez utóbbi szerepében megtapasztalt nyelvi és pragmatikai problémákról számolt be sok humorral, plasztikus példákkal Prekäre Situationen und Pragmatik beim Dolmetschen című elöadásában. Az előadó felvillantott néhány, jellemzően tolmácsolási szituációban felmerülö és a két kultúra különbségeiben rejlő nyelvi problémát, amelyek megoldásához pragmatikai ismereteinkre (is) támaszkodhatunk: pl. Hogyan fordítsuk magyarra, azt hogy Frau Kiss?, Hogyan tudjuk egy olasz névröl eldönteni, hogy férfit vagy hölgyet takar?, Mit tegyen a tolmács, ha politikailag inkorrekt szóhasználattal él az előadó (lásd Zigeuner vs. Roma)?, Hogyan pozícionáljuk a magyar pártokat, és hogyan fordítsuk a megnevezésüket ( Jobbik - eine rechte Partei)?.

A délelőtti blokk harmadik előadója, Einhorn Ágnes (az Idegen Nyelvi Központ docense) pedagógiai szempontból közelítette meg a témát Was sollte man unterrichten? - Überlegungen zu den Unterrichtshalten címü elöadásában az innovatív pedagógia főbb irányairól, ezen belül pedig a nyelvoktatás, valamint a fordító- és tolmácsképzés területén különösen hangsúlyos elemekről beszélt, mint pl. a kompetenciafejlesztés, a tanulói autonómia, a gamifikáció vagy a fejlesztő értékelés, amelyek a tanulóközpontú, kompetencia- és tevékenységalapú megközelítés kapcsán játszhatnak kulcsszerepet. A tanítási tartalmak mellett az előadó tehát nemcsak a Mit tanítsunk? kérdésére próbált meg választ találni, hanem a Hogyan tanítsunk? kérdésre is értékes alternatívakat mutatott be.

A délelött második felében két igen érdekes program várta az érdeklődőket. A Budapesti Goethe Intézet képviseletében Ilka Seltmann igazgatóhelyettes mutatta be a kulturális intézet budapesti tevékenységét, illetve honlapját. Goethe Web - Quelle für inspirierende Texte címü előadásából megtudhattuk, hogy a honlap nemcsak a Goethe Intézet nyelvvizsgái iránt érdeklődők számára bizonyulhat hasznosnak, hanem a német nyelv oktatóinak is értékes forrás lehet. A Kultúra rovatban (https://www.goethe.de/ins/hu/de/kul/mag.html) például számos olyan érdekes és aktuális hír szerepel, amelyet akár írott szövegértésre, de akár fordítási gyakorlatra is használhatnak az oktatók.

A BME Idegen Nyelvi Központ német anyanyelvi lektora, Benjamin Coester klasszikus értelemben vett műhelymunkára várta a délelőtti előadás-sorozat kitartóbb és németül megszólalni is hajlandó látogatóit. A Bewerben auf Deutsch: Lebenslauf, Anschreiben und Vorstellungsgespräch elnevezésü worskhop azt próbálta körüljárni, hogy melyek a jellemző hasonlóságok és különöségek a német és a 
magyar kultúra között a fenti müfajok (önéletrajz, kísérőlevél és állásinterjú) tekintetében; és melyek azok a jellemző hibák, amelyeket célszerü elkerülnünk, ha német nyelven pályázunk egy álláshirdetésre.

Az öszi konferencia második részében - talán elmondható, hogy már hagyományosan -nagyobb figyelmet kapott a praktikum. Ebben az évben a tolmácsolás müvelöinek és oktatóinak szerettünk volna fórumot nyitni, amelyen a szakma és az egyetem képviselöi közötti párbeszéd kerül előtérbe.

A délutáni szekcióban két eseményre invitáltuk az érdeklődőket; mindkettő a tolmácsoláshoz szükséges puha készségeket vette górcső alá. Az első blokkban a BME TFK két korábbi hallgatójának témafelvezető előadásait hallgathattuk meg, akik az előző évi konferenciatolmács záróvizsga részeként készített kutatásukat mutatták be. Horváth Patrícia a kísérötolmácsolás során tapasztalható empátia kérdéskörét boncolgatta sok-sok személyes tapasztalat és megvalósított interjú kapcsán, Moharos Éva pedig a tolmácsok stresszkezelésével kapcsolatos minikutatásának eredményeiről számolt be. A tolmácskutatásban nagy mintának számító kérdőíves kutatásból (128 válaszadó!) többek között a következő tanulságok vonhatók le: (1) saját bevallásuk szerint a gyakorló tolmácsok $89 \%$-a megfelelően kezeli a stresszt; (2) a megkérdezettek mintegy 45\%-a ítéli hasznosnak vagy pozitívnak a stresszt munkája során, míg 33\% ártalmasnak találja. Legalább ennyire érdekes az az adat, hogy a válaszadók 26\%-a közömbös a kérdésben - tehát a stressz nem merül fel problémaként napi munkájuk során. (3) A felmérésben részt vevő tolmácsok 67\%-a azonosított stresszhez kapcsolódó betegséget a szervezetében, ugyanakkor (4) mind a 128 megkérdezett egyöntetüen a stresszkezelés kezelhetősége, alakíthatósága mellett foglalt állást. A vitafórum további részében a résztvevők érdekes ötleteket és személyes tapasztalatokat osztottak meg a stressz kezelése terén (pl. alvás, rendszeres testmozgás, mint például séta, futás vagy jóga, szórakozás, tudatos légzés, meditáció vagy kirándulás). A fórum a témát övező óriási érdeklődés miatt hamar kilépett a megszokott frontális keretek közül, és dinamikus beszélgetés alakult ki az előadó, a moderátorok és a meghívott vendégek - köztük számos oktató és vagy/gyakorló tolmács - között.

A 2019-es öszi konferencia záróakkordja a puha készségek kapcsán felvetödö szakmai és etikai kérdéseket állította középpontba. A mühelymunkát a BME TFK két tolmácsoktatója, Beták Patrícia és jelen beszámoló szerzője, Szabó Csilla vezette a négy csoportba osztott, mintegy 70 résztvevő aktív közremüködésével. A témákat az alábbi alcímek mentén jártuk körül: (1) Profik a pácban: kényes helyzetek a színpadon és a kabinban: esettanulmányok a tolmácsok mindennapjaiból - Ki mit tenne? (2) Buktatók a tolmácsok szerzödésében: Mi legyen benne? (3) Tolmácsetika-megbizók és tolmácsaik: Mit lehet és mit nem? (4) Egyesületi tagság és kapcsolatépités - Megéri? Mit kapok?

A workshop alighanem legemlékezetesebb pillanatait a SZOFT LIMO elnevezésü, szituációs szerepjátékot idéző helyzetgyakorlatok jelentették, amikor az önként jelentkezők (hallgatók és profi tolmácsok vegyesen) a hallgatóság elött rögtönöztek olyan piaci, jellemzően valós vitahelyzeteket, amelyben a tolmács 
elfogadhatatlan és/vagy kellemetlen helyzetben találta magát, és lehetőség szerint konszenzusos megoldásra kellett jutnia a megrendelövel. A mühelymunka közben és azt követően élénk eszmecsere alakult ki az egyes puha készségek fontosságáról, és a jelen lévő oktatóknak arra is lehetősége nyílt, hogy e készségek elsajátíthatóságáról és oktathatóságáról is beszéljenek. A BME Tolmács-és Fordítóképző Központja piaci szereplök nélkül, csak oktatók számára is rendszeresen szervez szakmai fórumot: a legutóbbi Tanár-Tanár Találkozón (2019 júniusában) a tolmácsvizsgákon alkalmazott (szummatív) értékelési technikákat vitatták meg a különböző képzőintézményekben oktató tanárok; a 2020 tavaszára tervezett találkozó témája pedig a tolmácsképzés folyamatában használt fejlesztő értékelés lesz (amelyre a helyzet függvényében alighanem online videokonferencia formájában kerülhet sor).

A BME Idegen Nyelvi Központja 2020. október 2-ára tervezi soron következő öszi konferenciáját, amelyre ismét egy különleges, ezúttal kifejezetten interdiszciplináris témával készülünk. Sokak számára ismert problematika az ún. „írásblokk" (writing block, Schreibblokade), amikor a szerző/fordító/nyelvtanuló valamely okból elakad az írásművel; ezt a kérdéskört fogjuk közelebbről is megvizsgálni az Idegen Nyelvi Központot is magában foglaló Gazdaságtudományi Kar egyes társtanszékeivel, tehát a témát nemcsak nyelvészeti és fordítástudományi oldalról, hanem kommunikációs és a pszichológiai szempontból is igyekszünk körüljárni. 